\title{
Tocantins Apiaká, Parirí and Yarumá as Members of the Pekodian Branch (Cariban)
}

\author{
Fernando O. de Carvalho \\ Programa de Pós-Graduação em Letras (PPGLET) \\ Universidade Federal do Amapá (UNIFAP)
}

\begin{abstract}
This brief paper expands on the discussion of the evidence for including the sparsely attested Pariri and (Tocantins) Apiaká doculects as part of the Pekodian branch of the Cariban language family, within a sub-branch that includes the Arára-Ikpeng dialect cluster but excludes Bakairí. The present discussion goes beyond mere formal/semantic similarities in the comparanda and shows that both Pariri and Apiaká share a number of sporadic developments with Ikpeng and Arára, and these suggest an intermediate, shared ancestor exclusive to these languages. I also advance some original claims on the diachrony of these languages, such as the adoption of loans from non-Cariban languages, and an interesting semantic development in their innovative forms for 'fire'. Based on this particular innovation, I conclude, tentatively, in favor of the inclusion of yet another doculect - Yarumá - in the same sub-branch.
\end{abstract}

Keywords: Cariban Languages; Apiaká; Parirí; Internal Classification.

\section{Introduction ${ }^{1}$}

The labels Apiaká and Pariri appear in the ethnohistorical and anthropological literature on the indigenous peoples of South America associated with two Cariban-speaking groups inhabiting the region between the lower and middle courses of the Xingu and Tocantins rivers, to the south of the Amazon river, in northern Brazil. ${ }^{2}$ Figure 1 below shows an inset of Nimuendajú's ethnolinguistic map of Brazil and adjacent regions, where the location of the relevant groups appear under the names 'Arára' and 'Pariri', both associated to the dates of the published reports identifying each of them:

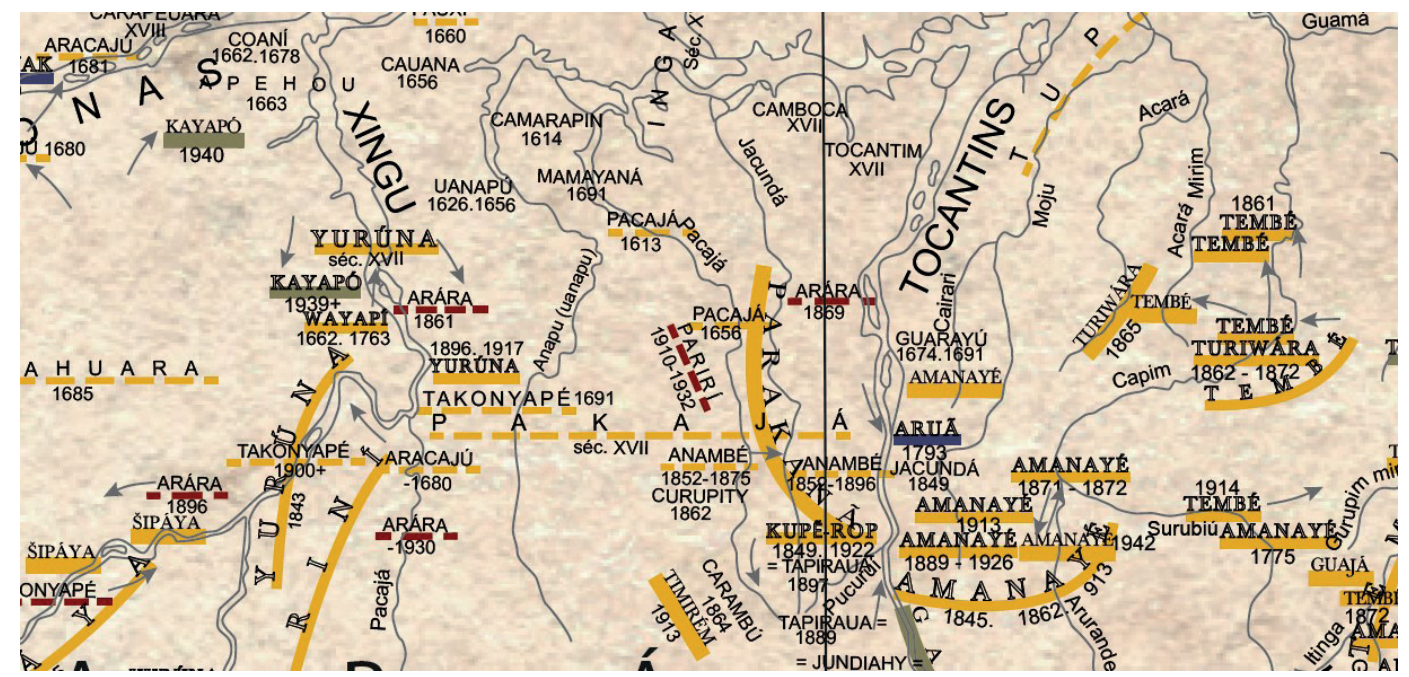

Figure 1. Inset from Nimuendajú's ethnolinguistic map of Brazil and adjacent regions, showing the location of the Arára, Pariri and Apiaká in the Xingu-Tocantins region (Nimuendajú 1987 [1944]).

1. I gratefully acknowledge an anonymous reviewer for his reading of this paper and for the relevant and fruitful commentary he/she offered on its contents. Needless to say, all remaining shortcomings this piece may have are of my entire responsability. 
In the map above the Apiaká appear identified as the rightmost group identified as 'Arára', close to the left bank of the Tocantins river (the reasons for this will soon become clear to the reader). Since both ethnonyms, silently yet unproblematically understood as glottonyms, happen to be associated with language material (being doculects, sensu CYSOUW; GOOD, 2013), it seem fitting to examine these sources in an attempt to inform our understanding of both the internal history of the Apiaká and Pariri languages and, possibly, as an additional source on the external history of the Cariban language family. ${ }^{3}$

As shown in section 2, the sources on Apiaká and Parirí have been examined in the past and a rather close proximity to Ikpeng, Arára and Bakairí, three independently attested Cariban languages that together make the Pekodian branch (MEIRA; FRANCHETTO, 2005), has been advanced. Published analyses of the data simply present a series of translational equivalents in a series of Cariban languages, with the goal of motivating an impression of greater proximity between Apiaká, Pariri and one or more of the Pekodian languages, as compared to other, less similar-looking Cariban languages (these were usually sampled from the lexical material published in Lucien Adam's well-known comparative study of the Cariban language family, published in 1893). In section 3, I will show that both Apiaká and Parirí have more than a set of similar lexical forms in common with the Arára-Ikpeng dialect cluster, ${ }^{4}$ sharing with the latter a set of sporadic developments in specific lexical items. Since these are shared innovations exclusively characteristic of Arára-Ikpeng, this evidence establishes, once and for all, the Pekodian affiliation of both Apiaká and Parirí. In particular, they point to a rather close relation between Parirí, Apiaká, Arára and Ikpeng. Section 4 is dedicated to the conclusions of the paper.

\section{The literature sofar}

In his 1894 landmark publication Unter den Naturvölkern Zentral-Brasiliens, Karl von den Steinen compares some selected lexical material that he obtained among the Bakairi with the (then unpublished) Ehrenreich materials on the language of the Apiaká of the Tocantins river. Though his ultimate aim was to inform his hypotheses on the homeland and posterior migrations of Cariban speakers (see STEINEN, 1894, p. 395-404 for an interesting and pioneering discussion on the matter), he noticed pronounced similarities between the two languages. Steinen finds that these similarities are 'not as close as those observed between some Carib groups of the north of the Amazon and the Bakairi' (STEINEN, 1894, p. 400), ${ }^{5}$ and concludes, based mainly on external evidence, that the Apiaka once lived close to the Bakairi, near the Paranatinga river and the upperTapajós.

2. Both terms have, however, a wider application that could lead to confusion. The label Apiaká is also applied to a TupiGuarani-speaking group of the upper Tapajós river. The modifier 'Tocantins' is thus often used as a way to avoid ambiguity. The label Arara is even more widespread, being applied in different locations of the Amazon as an exonym to diverse indigenous groups, such as the Karo (Tupian-speaking) of Rondônia and the Shawãdawa (Panoan-speaking) of Acre. This paper is focused on the Apiaká and Arára of the Xingu-Tocantins region.

3. The reader may be well aware of the fact that many ethnonyms in South America are casually treated as glottonyms, even in cases where no material, not even poorly transcribed wordlists, can be associated with these labels. Despite this, such 'ghost languages' are often included in classifications proposed by less cautious researchers.

4. Ikpeng and Arára are consensually accepted as co-dialects (MEIRA; FRANCHETTO, 2005, p. 130). Bakairí, the third member of the Pekodian subgroup is more distantly related and clearly stands as a separate language. In line with the published literature, I will at times use the expression 'Arára-lkpeng' as a reference to the two speech varieties.

5. From the original: 'Die sprachliche Verwandschaft der Apiaká und Bakaïri is eng, aber nicht enger als die einiger Karaibenstämme nördlich des Amazonas und der Bakaïr!!" (STEINEN, 1894, p. 400). 
In the nearly contemporary account of Ehrenreich (1895), Bakairi is also granted a special place in the comparison with Apiaká, if only because no data on the other Pekodian languages was available at the time. This changed with the publication of vocabulary data on both Pariri and Apiaká (NIMUENDAJÚ, 1914). After presenting his Parirí vocabulary, Nimuendajú (1914, pp. 624-625) adds very brief observations on the characteristic face painting and ornaments ${ }^{6}$ of the Parirí, concluding that: "alles das bestätigt nur, was schon aus dem Vokabular hervorgeht: dass die Pariri eine Bande desselben Karibenstammes sind, der am Xingú als Arára, am Tocantins als Apiaká aufgetaucht ist" [All of this reinforces what was established by the vocabulary: That the Pariri are part of the same Carib group that appears in the Xingu as Arára and in the Tocantins as Apiaká] (NIMUENDAJÚ, 1914, p. 625).

Nimuendajú (1914) explicitly proposes an identity between the Parirí, the Arára and the Tocantins Apiaká, all three being but regional individual communities (Bande) of the same group. Krause (1936) later brought to the picture the language of the Yarumá, another Cariban-speaking group that lived to the southeast of the Culvene river, one of the affluents of the Xingu. Krause (1936, p. 41) stressed the existence of a close relationship between Yarumá and (Tocantins) Apiaká.7 This later, more complete view was enshrined in two important reference works, the chapter on the indigenous groups of the Xingu-Tocantins region in the Handbook of South American Indians (NIMUENDAJÚ, 1948), and the well-known Durbin (1977) classification of the Cariban language family. Durbin (1977, p. 31) added Ikpeng, then known as 'Txicão', to the same cluster. In the more ethnologically-oriented discussion of the Handbook, Nimuendajú (1948, pp.223-225) fleshes out in greater detail how the three regional subgroups of his 1914 quote given above emerged, introducing the Pariri and the Apiaká as two Arára subgroups that migrated eastward, the Apiaká eventually arriving at the left/west bank of the Tocantins river. Since the Apiaká are identified in Nimuendajú (1948, pp. 224) as 'eastern Arára', it is not surprising that they are identified simply as 'Arára' in his ethnolinguistic map (cf. Figure 1).

Later and more recent reference works do not diverge from this picture outlined in the pioneering contributions and, by their nature as reference works, do not examine the issue of the internal classification of these languages in any detail. In the Kaufman (1994/2007) classification, Arara-Piriri (that is, Arára and Parirí), Apiaká and Txicão (that is, Ikpeng) are all members of the same Arára group of his southern branch. Gildea (2012, p. 445) presents a 'Arara group' internal to his Pekodian branch, including Arára (Parirí), and Ikpeng, with Bakairí as a separate group within Pekodian. The same basic structure is repeated in the current Glottolog classification, which differs only by the inclusion of Yarumá in the group, by the lack of any mention to Parirí, and by the use of 'Xinguan' as a label for the Pekodian languages other than Bakairí.

6. The same comparison of tattooing patterns was employed by Eherenreich (1895) to ascertain the Cariban affiliation of the Apiaká of the Tocantins, bringing them tentatively close to the Arára, and to identify them as a group different from their TupiGuarani-speaking homonyms of the Tapajós river.

7. From the original: "Interessante und wichtig ist die enge Sprachverwandschaft mit den Apiaká des unteren Tocantins" (KRAUSE, 1936, p. 41). Yarumá will not be discussed here in any detail, given that this doculect, differently from Apiaká and Parirí, does not show the bulk of the relevant evidence for the shared innovations with the Ikpeng-Arára dialect cluster that are focused in the present paper. However, it will be briefly addressed again in section 4, since it seems to share with these languages one particular innovation. 


\section{Innovations shared by Apiaká, Parirí and Ikpeng-Arára.}

As noted, the currently accepted classification of Apiaká as rather closely related to Arára-lkpeng (MEIRA; FRANCHETTO, 2005, p. 130), and the inclusion of Pariri in this same group (GILDEA, 2012, p. 445), have been arrived at mainly by the impressionistic consideration of similarities in vocabulary material.

I will now discuss the data in table $\mathbf{1}$, showing that they constitute evidence that a set of sporadic innovations, most of which were identified by Meira \& Franchetto (2005) as characteristic of Ikpeng are, first, also found in Arára and, second, also attested in Parirí and in Apiaká. See that these languages will be compared only with Bakairi in the table, as this is the closest relative of these languages, the other member of the Pekodian branch. Forms from other Cariban languages will be provided for comparison in the text below. Data from Apiaká come from Ehrenreich (1895), Parirí data from Nimuendajú (1914), Arara data from Alves (2010, 2013). Data from Ikpeng, unless explicitly noted otherwise, come from my own fieldwork at the Pavuru indigenous post, in the Xingu indigenous park. ${ }^{8}$

Starting at the left with the forms for 'arrow', Meira \& Franchetto (2005, p. 153-154) note the correspondence between word-final $m$ in Ikpeng pirom 'arrow' and $u / w$ (or zero) in other Cariban languages - compare, for instance: Kari'na pyrywa 'arrow' (COURTZ, 2008, p. 356); Proto-Taranoan *pirau 'arrow' (MEIRA, 2000, p. 136); Cumanagoto <preu> (YANGUE, 1683, p. 147); Pemón pöröu 'flecha' (GARCÍA FERRER, 2008, p. 204). Among the languages with the nasal-less forms for 'arrow' is Bakairí, the other member of the Pekodian branch, for which pirau 'arrow' is attested (see MEIRA, 2005, p. 273). The authors suggest a development $* V w V>* V w>* V m$ for Ikpeng, attributing the intermediate loss of the final vowel to syllable reduction, a change which was followed by the nasalization $*$ - $w>$ $-m .{ }^{9}$ Syllable reduction is a well-known, but still poorly understood process that takes place in one form or another in every Cariban language (see GILDEA,1995, for a classic comparative discussion of the phenomenon). What matters for the moment is that Meira \& Franchetto (2005), within the immediate purview of their reconstruction of Proto-Cariban phonology, quite correctly brush aside cases of syllable reduction as being matters of 'language-specific unpredictable idiosyncrasies' (MEIRA; FRANCHETTO, 2005, p. 134). On *-w >-m word-finally, this is suggested for lkpeng on the basis of two examples only ('arrow' and the locative for liquids -gwam; see MEIRA; FRANCHETTO, 2005, p. 154), and is somewhat weakened by the existence of - Vw final diphthongs in Ikpeng. Meira \& Franchetto (2005) note the case of pow 'peccary', and suggest that the match to forms such as Hixkaryana honko 'peccary' (where $h<{ }^{*} p$ ) might involve a so far unindentified morpheme, - $n k o$ in Hixkaryana, that would lack a match in Ikpeng. Still, it is not clear what would be the correspondent of Ikpeng final $-w$ in Hixkaryana and the other languages after the extraction of this post-base material (for Ikpeng pow 'peccary', only -o appears in the correspondences given by the authors; see MEIRA;

8. These fieldwork activities were part of the project 'Língua Ikpeng: Contribuições para a prática escolar e para o conhecimento científico' led by Prof. Dr. Angela Chagas (Universidade Federal do Pará) and having the author of this paper, and Prof. Dr. Eduardo Vasconcelos (Universidade Federal do Amapá), as members. Sources are abbreviated as follows in the table: Ehrenreich $(1895)=$ E95, Nimuendajú $(1914)=$ N14, Alves $(2010)=$ A10, Alves (2013) $=$ A13, Meira $(2005)=$ M05, Meira $\&$ Franchetto $(2005)=$ MF05.

9. The reader is referred to Meira \& Franchetto (2005) for the full argumentation justifying the reconstruction of * $w$, and not ${ }^{*} m$, for the Proto-Cariban (PC) etymon for 'arrow'. This is, of course, vital, since if PC had $* m$ instead here would be no Ikpeng innovation to begin with. The core reason for not reconstructing a nasal is that it would imply a series of ad hoc losses of nasal consonants in the other Cariban languages. 
FRANCHETTO, 2005, p. 170). Be as that may, the fact is that the derivation of Ikpeng pirom 'arrow' calls for the postulation of a language-specific, idiosyncratic process of syllable reduction, followed by the operation of a still poorly understood development nasalizing *-w. There is, moreover, a strict relative chronology for these developments, as final vowel loss ('syllable reduction') is necessary to feed the operation of final $*-w>m$. The fact that Apiaká and Parirí, not to mention Arára, display cognates that call for the same analysis is a significant match, and one that applies to these languages alone among known Cariban languages.

Two Ikpeng forms are discussed in Meira \& Franchetto (2005, p. 149) because they display a surprising velarization of a coronal nasal, $*_{n}>\eta$ : konpo 'rain' and manari 'breast' (compare: Proto-Taranoan *konopo 'rain' and *-manati 'breast' (MEIRA, 2000, p. 142, 193); Pemón konok 'lluvia' and manat 'seno' (GARCÍA FERRER, 2008, p. 210, 218), Kari'na konopo 'rain' and -manaty 'breast' (COURTZ 2008, p. 298, 312)). Again, Bakairí shows no evidence for any of these innovations: kopa 'rain' (MEIRA, 2005, p. 274) and $i$-wãr' 'breast' (MEIRA; FRANCHETTO, 2005, p. 181)..$^{10}$ The developments are surprising because the regular development of intervocalic * $n$ in Ikpeng is $n$, while it is subject to a velar shift, $* n>\eta$ when preceding a rhotic $r$ (MEIRA; FRANCHETTO, 2005, p. 149). As shown in table $\mathbf{1}$, both Apiaká and Pariri (the latter has no attested form for 'breast') display the same velar nasal stop. Ehrenreich (1895, p. 171) explicitly notes $\langle\dot{n}>$ as 'Gutturale', a member of the same series as $\langle k>$ and $\langle g\rangle$, and although Nimuendajú (1914) presents no transcription key, his other works reveal the use of the same convention (see e.g. NIMUENDAJÚ, 1925, p. 148). This velarization seems to lack any contextual phonetic motivation, which prompts its interpretation as a sporadic modification. As it is rather unlikely that three or four independent languages would be independently innovate the same sporadic modification ( ${ }^{*} n>\eta$ ) in the same two (unrelated) lexical items, it is best to assume that these sporadic developments occurred only once, at the level of some common ancestor uniquely shared by these four doculects.

Table 1: Comparative data for the Pekodian languages

\begin{tabular}{|c|c|c|c|c|c|}
\hline & 'arrow' & 'rain' & 'breast' & 'fire' & 'bird' \\
\hline Apiaká & $\begin{array}{c}<\text { pirom> } \\
\text { 'Pfeil' (E95:173) }\end{array}$ & $\begin{array}{c}<k o \dot{p} p o> \\
\text { 'Regen' (E95:173) }\end{array}$ & $\begin{array}{c}<\text { i-manarüe } \\
\text { 'Brust des Weibes' (E95:172) }\end{array}$ & $\begin{array}{c}<\text { <ampot> } \\
\text { 'Feuer' (E95:172) }\end{array}$ & $\begin{array}{c}<\text { talem> } \\
\text { 'Vogel' (E95:174) }\end{array}$ \\
\hline Parirí & $\begin{array}{c}<p u y r o ́ m> \\
\text { 'Pfeil' (N14:622) }\end{array}$ & $\begin{array}{c}<\text { <ońpó> } \\
\text { 'Regen' (N14:621) }\end{array}$ & - & $\begin{array}{c}<\text { kampó> } \\
\text { 'Feuer' (N14: 621) }\end{array}$ & - \\
\hline Ikpeng & pirom & konpo & -manart & atfi & talim \\
\hline Arára & $\begin{array}{c}\text { pirom } \\
\text { 'arrow', (A10:30) }\end{array}$ & $\begin{array}{c}\text { konpo } \\
\text { 'chuva' (A13:268) }\end{array}$ & $\begin{array}{c}\text { 'manari } \\
\text { 'my breast' (A10:25) }\end{array}$ & $\begin{array}{c}\text { kampot } \\
\text { 'fogo' (A13:273) }\end{array}$ & - \\
\hline Bakairí & $\begin{array}{c}\text { pirau } \\
\text { 'arrow' (Mo5: 273) }\end{array}$ & $\begin{array}{c}\text { kopə } \\
\text { 'rain' (Mo5: 274) }\end{array}$ & $\begin{array}{c}\text { i-wãri } \\
\text { 'breast' (MFo5: 181) }\end{array}$ & $\begin{array}{c}\text { peto } \\
\text { 'fire' (Mo5:266) }\end{array}$ & $\begin{array}{c}\text { konopio } \\
\text { 'bird' (MFo5:180) }\end{array}$ \\
\hline
\end{tabular}

10. Of course, Bakairí $i$-wãr ' 'breast' does not contribute any information on the Place of the medial nasal stop in the pre-Bakairí or Proto-Pekodian etymon, since all that is left of the lost nasal consonant is contextual nasalization of a vowel (Meira \& Franchetto, 2005, p. 147, suggest the development $* i$-wana-ri $>i-w \tilde{a}-r \dot{t}$ for Bakairí). Still, it does not offer any positive evidence that the (apparently) sporadic $*_{n}>\eta$ was also shared with Bakairí. 
Meira \& Franchetto (2005) discuss, among its cognate sets, one that could be explained as composed of reflexes of a Proto-Cariban etymon *wepoto 'fire' (MEIRA; FRANCHETTO, 2005, p.136), including Pemón apok 'fuego' (GARCÍA FERRER, 2008, p. 204), Proto-Taranoan *mapoto 'fire' (MEIRA, 2000, p. 158), Kari'na wàto 'fire' (<*wapoto; COURTZ, 2008, p. 424). Bakairí peto 'fire' (MEIRA, 2005, p. 266) is also plausibly part of this same set. Ikpeng atfi 'fire', however, is correctly judged not cognate with other Cariban forms (see MEIRA; FRANCHETTO, 2005, p. 183). I add, first, that this Ikpeng form is a likely loan from a language of the Jurunan branch of the Tupian language family, either Xipáya or Yudjá (cf. Xipáya <aší> 'Feuer' (NIMUENDAJÚ, 1928, p. 824; GALÚCIO et al., 2015, p. 259). Second, Arára, which is otherwise very closely related to Ikpeng, has a form kampot 'fire' (ALVES, 2013, p. 273), and given the close proximity between the two languages/co-dialects, it is plausible that *kampot was the Ikpeng form for 'fire' as well before the adoption of the Jurunan loan. ${ }^{11}$ Third, and more to the point, both Apiaká and Parirí have similar forms for 'fire', and this seems to constitute a lexical isogloss of this group of languages. The origin of this innovative form for 'fire' is somewhat obscure at present, but plausible cognates appear in other Cariban languages with the meaning 'smoked meat', as in ProtoTaranoan*kampa 'smoked meat' (MEIRA, 2000, p. 202), Kari'na kampo 'smoked meat' (COURTZ, 2008, p. 209), Wayana kanpë 'boucané', ipun kanpë 'viande boucaneé' (CAMARGO; TAPINKILI, 2009, p. 70) and Apalai kãpo 'smoked meat' (author field data). If the etymology suggested by Courtz (2008, p. 209) is correct, and kampo-like forms derive from *ka-, the same root seen in Kari'na katt 'body, fat', plus the 'former/devalued possession' suffix (some reflex of Proto-Cariban *-npa), then the meaning 'fire' in Arára, Parirí and Apiaká is clearly innovative (probably from an initial metonymic shift 'smoked meat' > 'fire for smoking meat', and later semantic broadening to 'fire'). Formally, there is still the problem of explaining the final - $t$ in Arára and Apiaká kampot 'fire', as it lacks a match in the presumably cognate vowel-final forms like Proto-Taranoan *kampa 'smoked meat'. One possibility is that this - $t$ reflects the possessive suffix -ti (GILDEA, 1992, p. 101-109; DERBYSHIRE, 1999, p. 40-41). Although reflexes of the 'devalued possession' suffix *-npa are only preceded but never followed by possessive suffixes in languages like Kari'na (see COURTZ, 2008, p. 69-70), other suffixes with a similar function and distribution do occur followed by the nominal possessive suffixes reconstructed for Proto-Cariban such as *-rit, *-ti and *-ni. Gildea (1992, p. 121-124) notes that reflexes of the Past Nominalizer suffix *-tupu (or *-tipi) occur followed by *-ri in languages like Chayma, Cumanagoto, Apalai and Hixkaryana, at least etymologically (see also GILDEA, 1992, p. 138-139). This same analysis seems to be independently adopted in some of the primary sources, such as Koehn \& Koehn (1986, p. 45, 55) on Apalai, where the suffix - vpyry is glossed as '-PAST+POSSN' ('POSSN' is the gloss attributed by the authors to the nominal possessive suffixes, and $-\tilde{v}$ denotes the nasalization of a preceding vowel). Note that for this to be a relevant parallel we would need to accept an identification/cognation between two sets of morphemes that are usually discussed in separate but which show suggestive functional and formal near-identities: the possessive suffixes, such as *-ri and *-ni (see GILDEA, 1992, p. 101-119; DERBYSHIRE, 1999, p. 4042) and the homophone nominalizers *-riand *-ni (see GILDEA, 1992, p. 121-145; DERBYSHIRE, 1999, p. 45-50). That the proposal is not outlandish is evident from the basically possessive morphosyntax of deverbal nominalizations featuring suffixes like *-tipi-ri (GILDEA, 1993, p. 47-51; DERBYSHIRE, 1999, p. 49), and we can plausibly assume that for some languages/stages in the diversification of Cariban languages it is not too forced to assume that *-npa 'devalued' could also occur followed by the possessive/nominalizing suffixes. Be as that may, the matter certainly deserves closer investigation.

11. Note, however, that kampot is attested in Ikpeng as a male proper name. 
Finally, the forms for 'bird', where Apiaká <talem> 'Vogel' (EHRENREICH, 1895, p. 174) matches Ikpeng talim 'bird' (NIMUENDAJÚ, 1914, did not record a general term for 'bird' for Parirí, only names of particularspecies). Meira \& Franchetto $(2005$, p. 149) suggest, first, that talim is 'a cognate with surprising vowels' of the widespread Cariban forms similar to torono or tonoro - see e.g. Kari'na tonoro 'bird', (COURTZ, 2008, p. 389), Proto-Taranoan *torono/*tonoro 'bird' (MEIRA, 2000, p. 140); Cumanagoto <torono> 'Aue, en comum' (YANGUES, 1683, p. 95); Pemón toron 'pájaro' (GARCÍA FERRER, 2008, p. 214) -, but end up concluding that it might be considered not cognate at all. The conclusion of noncognation seems correct, and whatever the ultimate origin of Ikpeng talim and Apiaká <talem $>$, their restriction to these languages constitutes a lexical isogloss that seems to set them apart from the rest of the Cariban language family. As for Bakairi, the other member of the Pekodian branch, the form konopio 'bird' (MEIRA; FRANCHETTO, 2005, p. 180) lacks plausible cognates in other Cariban languages and is best analyzed as a loan from some Arawakan language (see PAYNE, 1991, p. 395 for his proposed Proto-Arawakan etymon *kudipira 'bird'). ${ }^{12}$

\section{Conclusions - and a note on Yarumá}

This brief paper has brought to fore a series of innovations that single out a subgroup of Cariban languages - Ikpeng, Arára, Parirí and Apiaká do Tocantins - as a bona fide, if low-level, clade of this family. Though a modest contribution, it does succeed in establishing in terms of the methodologically more rigorous standard defined by the identification of sets of shared innovations what was once recognized only on the basis of impressionistic assessment of similarity. The developments discussed here, along with their distribution among the languages that make the Pekodian branch of the Cariban language family, are presented in table $\mathbf{2}$ :

Table 2: Distribution of discussed innovations among Pekodian languages

\begin{tabular}{|l|c|c|c|c|c|}
\hline \multirow{2}{*}{ Innovations } & \multicolumn{5}{|c|}{ Pekodian languages } \\
\cline { 2 - 6 } & Ikpeng & Arára & Apiaká & Parirí & Bakairí \\
\hline Unmotivated/sporadic * $w>m$ & $\checkmark$ & $\checkmark$ & $\checkmark$ & $\checkmark$ & $\mathrm{x}$ \\
\hline Unmotivated/sporadic $* n>\eta$ & $\checkmark$ & $\checkmark$ & $\checkmark$ & $\checkmark$ & $\mathrm{x}$ \\
\hline Innovative form for 'fire' & $\checkmark$ & $\checkmark$ & $\checkmark$ & $\checkmark$ & $\mathrm{x}$ \\
\hline Isolated/exclusive form for 'bird' & $\checkmark$ & $?$ & $\checkmark$ & $?$ & $\mathrm{x}$ \\
\hline
\end{tabular}

Since each of the relevant doculects has its own particularities, some of which may derive from limitations in the existing records rather than from 'real' properties of the varieties they represent, they are best entered as separate labels in classifications, instead of having, say, Pariri as a variety of Arára, when it could, with equal justice, be described as a variety of Ikpeng. The structure I propose for this internal structure of the Pekodian branch is given in (1).

12. The presence of Arawakan elements in Bakairi was first noticed by Steinen (1892) in relation to the names of the two

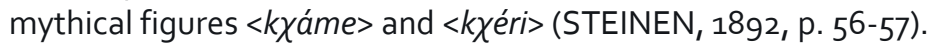


(1) Internal structure of the Pekodian branch of the Cariban family

Pekodian branch

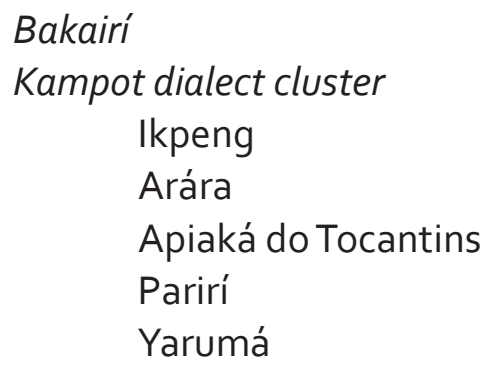

The name 'Kampot' is here suggested, first, for its neutrality (as it does not adopt the label of one specific variety as a cover term for the sub-branch), and, second, for its convenience, since it is chosen after what is arguably one of the most interesting and distinguishing innovations setting this group of dialects/varieties from the rest of the family. Finally, note that Yarumá has also been included in (1) as part of the Kampot dialect cluster. The fragmentary attestation of this language, recorded by Wilhelm von den Steinen and Hermann Meyer, later published in Krause (1936), does not include forms for any of the meanings considered in table $\mathbf{1}$, thus being critically uninformative, with one exception. A form for 'fire' is noted: <kampón> (KRAUSE, 1936, p. 40). Since this form clearly fits within the same innovative set discussed in section $\mathbf{3}$, and since this innovation was singled out as the hallmark of this sub-branch, it is just natural that Yarumá should as well be recognized as part of this clade.

\section{References}

ADAM, Lucien. Matériaux pour servir à l'établissement d'une grammaire compareé des dialectes de la famille Caribe. Paris: J. Maisonneuve, 1893.

ALVES, Ana Carolina. Phonological aspects of Arara (Carib, Brazil). M.A. Thesis, Radboud Universiteit Nijmegen, 2010.

ALVES, Ana Carolina. Aspectos do sistema fonológico do Arara (Karib). Boletim do Museu Paraense Emílio Goeldi, v. 8, n. 2, p. 265-277, 2013.

CAMARGO, Eliane; TAPINKILI. Hakëne omijau eitop Wajana-Palasisi (Dictionnaire Bilingue WayanaFrançais). CELIA/DRAC-Guyane/TEKUREMAI, 2009.

COURTZ, Henk. A Carib grammar and dictionary. Toronto: Magoria Books, 2008.

CYSOUW, Michael; GOOD, Jeff. Languoid, doculect, glossonym: Formalizing the notion 'language'. Language Documentation and Conservation, v. 7, p. 331-359, 2013.

EHRENREICH, Paul. Materialien zur Sprachenkunde Brasiliens: V. Die Sprache der Apiaka (Para). Zeitschrift für Ethnologie, v. 27, p. 168-176, 1895.

GALÚCIO, Ana Vilacy; MEIRA, Sérgio; BIRCHALL, Joshua; MOORE, Denny; GABAS JR., Nilson; DRUDE, Sebastian, STORTO, Luciana; PICANÇO, Gessiane; RODRIGUES, Carmen R. Geneological relations and lexical distances within the Tupian language family. Boletim do Museu Paraense Emílio Goeldi, v. 10, n. 2, p. 229-274, 2015.

GARCÍA FERRER, Donaldo. Diccionario piloto Pemón-Español. Master's Thesis, Universidad del Zulia, Venezuela, 2008. 
GILDEA, Spike. Comparative Cariban morphosyntax: On the genesis of ergativity in independent clauses. Doctoral dissertation, University of Oregon, 1992.

GILDEA, Spike. The rigid VS order in Panare (Cariban): A historical explanation. International Journal of American Linguistics, v. 59, n. 1, p. 44-63, 1993.

GILDEA, Spike. A comparative description of syllable reduction in the Cariban language family. International Journal of American Linguistics, v. 61, n.1, p. 62-102, 1995.

GILDEA, Spike. Linguistic studies in the Cariban family. In CAMPBELL, Lyle; GRONDONA, Verónica (Eds.). The indigenous languages of South America: A comprehensive guide. Berlin: De Gruyter Mouton, 2012, p. 441-494.

KAUFMAN, Terrence. The native languages of South America. In MOSELEY, Christopher; ASHER, R. (Eds.). Atlas of the World's Languages. New York: Routledge, 1994, p. 46-76.

KAUFMAN, Terrence. South America. In ASHER, R.; MOSELEY, Christopher; (Eds.). Atlas of the World's Languages. 2ed. London: Routledge, 2007, p. 59-94.

KRAUSE, Fritz. Die Yaruma- und Arawine-Indianer Zentralbrasiliens. Baessler-Archiv, v. 19, p. 32-44, 1936.

MEIRA, Sérgio. 2000. A reconstruction of Proto-Taranoan: Phonology and morphology. $\quad \mathrm{M}$ u $\mathrm{n}$ i c $\mathrm{h}$ : LINCOM Europa.

MEIRA, Sérgio. Reconstructing Pre-Bakairi segmental phonology. Anthropological Linguistics, v. 47, n. 3, p. 261-291, 2005.

MEIRA, Sérgio; FRANCHETTO, Bruna. The Southern Cariban languages and the Cariban Family. International Journal of American Linguistics, v. 71, n. 2, p. 127-192, 2005.

NIMUENDAJÚ, Curt. 1914. Vokabular der Parirí-Sprache. Zeitschrift für Ethnologie 46: 619-625.

NIMUENDAJÚ, Curt. 1925. As tribus do Alto Madeira. Journal de Société des Américanistes 17: 137 172.

NIMUENDAJÚ, Curt. Wortliste der šipáya-Sprache. Anthropos, v. 23, n. 5/6, p. 821-850, 1928.

NIMUENDAJÚ, Curt. Tribes of the lower and middle Xingú river. In: STEWARD, Julian (Ed.). Handbook of South American Indians, Vol. 3. Washington: Government Printing Office, 1948, p. 213-243.

NIMUENDAJÚ, Curt. Mapa Etno-Historico do Brasil e Regiões Adjacentes. Segunda Impressão. Rio de Janeiro: Fundação Nacional Pró-Memória; IBGE, 1987 [1944].

PAYNE, David. A classification of Maipuran (Arawakan) languages based on shared lexical retentions. In DERBYSHIRE, Desmond; Pullum, G. K. (Eds.). Handbook of Amazonian Languages. The Hague: Mouton de Gruyter, 1991, p. 355-499.

STEINEN, Karl von den. Die Bakaïri-Sprache. Leipzig: K. F. Koehler's Antiquarium, 1892.

STEINEN, Karl von den. 1894. Unter den Naturvölkern Zentral-Brasiliens. Berlin: Dietrich Reimer.

YANGUES, Manuel de. Principios y reglas de la lengua Cummanagota. Leipzig: B.G. Teubner. 1888 [1683]. 